\title{
PENINGKATAN KEMAMPUAN SISWA MENULIS BAHASA INGGRIS NARRATIVE TEXT MELALUI MEDIA GAMBAR BERSERI
}

\author{
Nurhayati \\ Guru SMP Negeri Satu Atap Teratak Baru Kecamatan Kuantan Hilir.
}

\begin{abstract}
ABSTRAK. Tujuan dari penelitian ini adalah untuk meningkatkan kemampuan siswa menulis teks narratif dalam bahasa Inggris dengan menggunakan media gambar berseri. Objek penelitian ini adalah siswa kelas VIII SMP Negeri Satu Atap Teratak Baru Kecamatan Kuantan Hilir. Penelitian ini menggunakan metode Penelitian Tindakan Kelas Kuantitatif yang dilaksanakan dalam 2 siklus, dalam penelitian ini teknik pengumpulan datanya menggunakan observasi dan tes (pre test dan post test). Hasil penelitian ini menunjukan bahwa terjadi peningkatan pembelajaran yang dilakukan siswa kelas VIII dengan demikian dapat disimpulkan bahwa dengan memanfaatkan media gambar berseri dapat meningkatkan kemampuan menulis berbahasa Inggris teks naratif siswa. Hal itu terlihat dari hasil rata-rata pos-test pada siklus 2 dari 80 meningkat menjadi 85. Hasil observasi memperlihatkan aktivitas guru dalam mengajar mengalami peningkatan baik pada kondisi awal pada siklus I maupun siklus II.
\end{abstract}

Kata kunci: Teks Naratif, Tindakan Kelas, Menulis,

\section{IMPROVING STUDENTS' ABILITY IN WRITING ENGLISH NARRATIVE TEXT THROUGH PICTURE SERIES MEDIA}

\begin{abstract}
The aim of this study is to improve students' ability in writing narrative text in English by using picture series media. The object of this study is the Eighth grade students of one-roof Junior High School Teratak Baru Kuantan Hilir district. This study used the quantitative classroom action research which was carried out in 2 cycles, in this study the data collection technique used observation and tests (pre-test and post-test). The result of this study showed that there is an increasing in learning by students of eighth grade, consequently it can be concluded that by utilizing picture series media can improve students' ability in writing English narrative text. It can be seen from the result of the average post-test in cycle 2 of 80 increased to 85. The result of the observation showed that the teacher's activities in teaching increased in both early condition in the cycle I and cycle II.
\end{abstract}

Key Word : Narrative Text, Classroom Action Research, Witing.

\section{PENDAHULUAN}

Bahasa Inggris sebagai bahasa internasional merupakan bahasa yang penting untuk dikuasai baik secara tulis ataupun lisan. Karena itu perlu membekali anak didik kita agar dapat menguasai bahasa Inggris dengan sebaik-baiknya. Guru sudah seharusnyalah mampu menumbuhkan dan membangkitkan rasa percaya diri para siswa agar kelak mereka mampu menghadapi era globalisasi. Pada pembelajaran Bahasa Inggris SMP baik kelas 7, 8, dan 9, pembelajaran menulis (Writing) merupakan salah satu kompetensi yang harus diajarkan pada siswa. Silabus 
pembelajaran bahasa Inggris kelas 8 semester genap, mengamanatkan agar siswa mampu: Mengungkapkan makna dan langkah retorika dalam essai pendek sederhana dengan menggunakan ragam bahasa tulis secara akurat dan lancar

Namun kenyataannya bahwa siswa seringkali mengeluh dan mengatakan sulit bila guru memberi tugas pada siswa untuk menulis. Bahkan acapkali siswa sudah mengatakan tidak bisa walaupun belum dimulai. Siswa terlihat tidak percaya diri bila diberi tugas menulis. Mereka merasa takut tidak dapat menyelesaikan tugas menulis, karena tidak tahu apa yang harus ditulis, bagaimana cara memulainya dan mengakhirinya.

Dari kenyataan adanya permasalahan yang dihadapi oleh peserta didik, maka sudah seharusnyalah guru mencari cara agar peserta didik tidak berkecil hati bila diberi tugas menulis. Sehingga penulis mencari cara dengan memanfaatkan media gambar berseri yang menarik bagi siswa/peserta didik agar dapat memberikan motivasi bagi mereka supaya bersemangat dan mampu untuk menulis. Dan karena pada KD 12.2 salah satu kompetensi yang ingin dicapai adalah menulis teks sederhana berbentuk narrative dengan langkah retorika yang benar, maka penulis melakukan penelitian tentang penggunaan gambar-gambar berseri yang menceritakan kisah berbentuk naratif yaitu Pinokio dan Cinderella sebagai media ajar. Untuk meningkatkan kemampuan menulis (writing) siswa penggunaan media ajar gambar berseri Pinokio dan Cinderella mampu meningkatkan kemampuan menulis (writing) siswa. Tujuan penelitian tindakan kelas yang dilaksanakan pada siswa kelas VIII, untuk meningkatkan kemampuan siswa dalam menulis teks narrative berbahasa Inggris pada siswa SMP Negeri Satu Atap Teratak Baru

Kecamatan Kuantan Hilir.

\section{METODE PENELITIAN}

Penelitian ini adalah penelitian tindakan kelas. Instrumen penelitian ini adalah penggunaan media gambar-gambar berseri dengan kisah Pinocchio dan Cinderella. Pemilihan kedua cerita tersebut berdasarkan hasil angket siswa. Mereka merasa lebih familier dan senang dengan kedua kisah tersebut. Pengumpulan data dalam penelitian ini menggunakan tes tertulis, lembar observasi, dan dokumentasi (foto/video proses kegiatan pembelajaran). Agar diperoleh data yang valid, maka semua data dilakukan validasi. Data-data hasil observasi, baik itu berupa aktivitas siswa ketika berlangsungnya pelaksanaan tindakan Siklus I dan Siklus II maupun kinerja guru saat melakukan tindakan pada siswa divalidasi dengan cara trianggulasi sumber, yakni dengan cara berkolaborasi dengan teman sejawat yang berperan sebagai observer. Trianggulasi merupakan teknik pemeriksaan keabsahan data yang memanfaatkan sesuatu yang lain untuk keperluan pengecekan (Lexy J. Moleong, 178).

Dalam menjalankan tugasnya, observer menggunakan lembar observasi yang telah disiapkan oleh peneliti untuk mengamati berlangsungnya proses pembelajaran ketika Siklus I dan Siklus II berlangsung. Sedangkan data hasil belajar bahasa Inggris yang diperoleh melalui tes tulis, divalidasi dengan cara membuat butir soal dan kisi-kisi yang sesuai dengan pedoman dalam kurikulum dan RPP. Yang 
kesemuanya telah disupervisi dan diketahui oleh Kepala Sekolah.

Analisis data pada penelitian ini dengan menggunakan teknik deskriptif komparatif, yaitu analisis yang menggambarkan perbandingan proses berlangsungnya pembelajaran pada kondisi awal, saat Siklus I, dan Siklus II. Begitu pula hasil belajar yang diraih siswa dari saat kondisi awal, ketika Siklus I dan Siklus II. Peneliti mendeskripsikan dan memperbandingkan data perolehan hasil belajar siswa pada kondisi awal dengan data hasil belajar yang diperoleh siswa pada Siklus I. Kemudian data hasil belajar siswa dari Siklus I dideskripsikan dan diperbandingkan dengan data hasil belajar siswa pada Siklus II. Selanjutnya pada pembahasan akhir dideskripsikan serta diperbandingkan hasil belajar siswa yang dicapai antara kondisi awal dan kondisi akhir (Siklus II).

Analisis data penelitian ini dilakukan dalam suatu proses, pengumpulan data di awal sebelum tindakan, lalu saat Siklus I dan Siklus II dilaksanakan. Dan setiap kali pemberian tindakan berakhir, maka data yang terkumpul dianalisis berdasarkan hasil observasi aktivitas siswa, aktivitas guru, dan hasil kerja siswa.

Prosedur Penelitian Penelitian ini dirancang untuk dilaksanakan dalam dua siklus yaitu Siklus I dan Siklus II.

Penelitian ini dilaksanakan dalam dua siklus yaitu Siklus I dan Siklus II. Perbedaan kedua siklus terletak pada judul tema dari gambar berseri yang digunakan yaitu Siklus I menggunakan buku cerita Pinochio, sedangkan Siklus II memakai Cinderella. Pemilihan keduanya disesuaikan dengan tujuan yang ingin dicapai pada Kompetensi Dasar 12.2 untuk siswa kelas VIII semester genap. Adapun tahapan perencanaan dan pelaksanaan kedua siklus tersebut pada prinsipnya adalah sama, sebagaimana pendapat Kemmis dan Mc Taggart (1988) bahwa siklus terdiri atas a) perencanaan (Planning), b) tindakan (Acting), c) pengamatan (Observing), dan d) refleksi (Reflecting).

1. Perencanaan (Planning)

Peneliti merancang tindakan berdasarkan tujuan penelitian sebagaimana telah dijabarkan di atas. Beberapa instrumen yang disiapkan yaitu rencana pembelajaran (RPP), buku bahan ajar, lembar kerja untuk siswa (kertas folio bergaris), lembar observasi, Media Ajar berupa gambargam-bar berseri, dan kamera foto. Gambar berseri dengan kisah Pinokio dipilih untuk Siklus I dan Cinderella untuk Siklus II. Semua instrumen tersebut divalidasi oleh rekan sejawat dan telah diizinkan serta disetujui oleh Kepala Sekolah.

2. Pelaksanaan Tindakan (Acting)

Kegiatan pokok dalam penelitian tindakan kelas pada Siklus I ini dapat dipaparkan tahapannya yaitu: Kegiatan Pendahuluan, Kegiatan Inti, dan Kegiatan Penutup. Kegiatan pendahuluan mencakup doa, presensi, pemberian motivasi dan apersepsi serta penjelasan tentang tujuan pembelajaran terkait KD 12.2 yang hendak dicapai. Kegiatan inti mencakup penjelasan ciri-ciri kebahasaan teks berbentuk narrative, tata bahasa Past Tense, dan kosakata terkait tema dan jenis teks; pembagian 8 kelompok; penjelasan tentang kegiatan yang akan dilaksanakan yaitu menulis teks pendek dan sederhana dalam bentuk narrative 
dengan dibantu media gambar berseri berkisah tentang Pinokio; siswa untuk menulis cerita sederhana tentang Pinokio sesuai dengan gambar-gambar berseri; pemantauan kegiatan kelompok; pengumpulan hasil tulisan dan dievaluasi oleh guru; diskusi kesulitan dan solusinya; dan penegasan pesan moral (moral value) dari cerita narrative yang telah mereka buat. Sedangkan Kegiatan penutup meli-puti pemberian apresiasi pada semua siswa, pemberian tugas mandiri, dan do'a penutup.

3. Pengamatan (Observing)

Selama pelaksanaan tahap Tindakan, peneliti melakukan pengamatan/observasi terhadap aktivitas kegiatan siswa saat beraktivitas dalam kelompok dan mengerjakan tugas sesuai dengan gambargambar yang telah diterimanya. Pengamatan dilakukan dengan menggunakan instrumen berupa lembar observasi yang telah disiapkan. Komponen dalam lembar observasi men-cakup rekaman atas pengamatan proses pembelajaran mulai tahap pendahuluan, kegiatan inti, dan penutup

4. Refleksi (Reflecting)

Isian lembar instrumen pengamatan (lembar observasi) kegiatan pembelajaran dikaji secara teliti. Masukan-masukan serta kritikan-kritikan yang membangun dari guru observer ditindaklanjuti untuk perbaikan dan peningkatan kegiatan pembelajaran pada siklus berikutnya. Wawancara secara informal pada beberapa siswa saat jam istirahat juga menjadi masukan yang sangat berarti untuk peningkatan kegiatan pembelajaran selanjutnya. 9 Hasil belajar siswa dalam bentuk lembar kerja (kertas folio bergaris) dikaji lebih mendalam dalam tahapan ini. Hasil belajar dipaparkan dalam bentuk tabel agar lebih komunikatif. Dalam tabel Indikator Capaian Belajar tersebut mencakup elemen-elemen yang akan dinilai dari hasil tulisan setiap siswa yaitu Grammar, Spelling, Diction, Cohesion, dan Handwriting.

Pengkajian juga dilakukan terhadap aspek proses pembelajaran yang berlangsung yang telah terekam dalam hasil observasi/pengamatan terhadap aktivitas siswa dan guru, serta penggunaan media ajar tersebut. Dari kegiatan refleksi terhadap hasil belajar siswa dan hasil observasi serta wawancara pada siswa, dapat ditentukan langkah lanjut dalam kegiatan pembelajaran berikutnya, agar kegiatan belajar mengajar lebih optimal dan mengantarkan siswa pada pencapaian kompetensi dasarnya. Empat tahapan di atas tidak hanya dilakukan pada Siklus I, tetapi juga dilaksanakan pada Siklus II. Hasil refleksi dari Siklus I menjadi dasar bagi pelaksanaan Siklus II terutama tahapan perencanaan dan tindakan. Pada Siklus II dilakukan tindakan yang lebih baik, agar kekurangan-kekurangan yang terjadi di Siklus I tidak terulang lagi di Siklus II.

\section{HASIL DAN PEMBAHASAN}

Sebelum dilakukan penelitian tindakan kelas, keadaan siswa kelas VIII pada kondisi awal saat berlangsungnya proses pembelajaran cenderung pasif. Para siswa hanya ingin menjadi pendengar saja. Mereka merasa bahwa dengan mendengarkan guru saja, mereka dapat me- 
nyerap pelajaran dengan baik. Padahal untuk dapat menguasai pelajaran Bahasa Inggris, siswa seharusnyalah lebih banyak melakukan praktiknya dalam bahasa tersebut, baik secara lisan maupun tulis.

Selain itu, dari daftar nilai siswa kelas VIII pada kondisi awal data menunjukkan bahwa ketika siswa diberi tugas untuk membuat essay pendek sederhana yang berbentuk teks recount, banyak siswa mendapatkan nilai di bawah Kriteria Ketuntasan Minimal (KKM) 70. Sedangkan nilai rata-rata kelas yaitu 65 . Perolehan nilai tertinggi siswa pada kondisi awal adalah 80, dan nilai terendah 40, sedangkan rentang nilai adalah 40. Dan ketika guru membagikan nilai hasil belajar siswa, guru menanyakan kepada siswa tentang kesulitan-kesulitan apa yang dialami oleh siswa saat menulis essay pendek sederhana (dalam hal ini guru melakukan wawancara lisan terhadap siswa). Lalu kebanyakan dari mereka mengatakan kalau menulis itu sulit, mereka tidak tahu apa yang akan ditulis, mereka tidak tahu harus memulai dengan kata dan kalimat yang bagaimana, mereka bahkan takut kalau yang ditulis nanti akan salah.

b). Hasil Tindakan Siklus I

Dalam pelaksanaan Siklus I yang mencakup Perencanaan (Planning), Tindakan (Acting), Pengamatan (Observing), dan Refleksi (Reflecting) diperoleh nilai hasil belajar siswa yang dapat diperoleh nilai terendah 45 , tertinggi 90 , rerata 80 , dengan rentang nilai 45. Jika diperbandingkan dengan nilai hasil belajar siswa yang diperoleh pada Kondisi Awal, dapat dikemukakan bahwa nilai terendah meningkat dari 40 menjadi 45, nilai tertinggi meningkat dari 80 menjadi 90, dan nilai rerata meningkat dari 65 menjadi 80 .

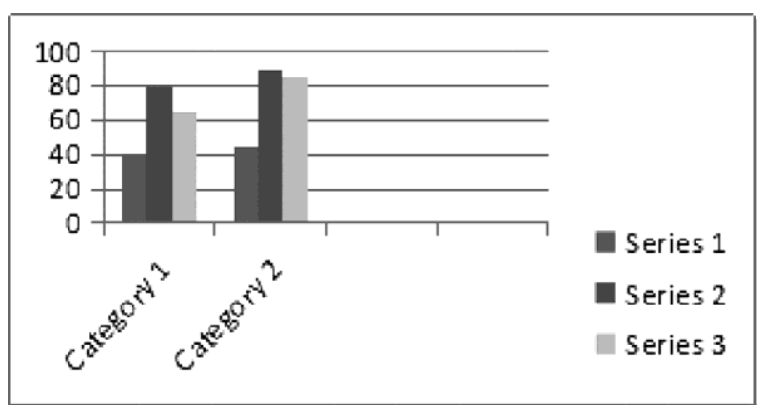

Diagram 1

Perbandingan Kondisi Awal dan Siklus I

Dari komparasi tersebut menunjukkan bahwa kegiatan pembelajaran Siklus I cukup berhasil meningkatkan hasil belajar siswa. Namun ada 5 siswa yang nilai hasil belajarnya masih di bawah KKM, sehingga siswa tersebut harus diremidi. pertemuan berikutnya, dilakukan remidi bagi ke 5 siswa tersebut, sekaligus pemberian pengayaan bagi 27 siswa lainnya yang nilainya mencapai atau melampaui KKM. Pada Siklus II diharapkan sudah tidak ada lagi siswa yang perlu diremidi.

Selanjutnya untuk pemberian tindakan pada Siklus II, juga dilakukan tahapan-tahapan yang sama dengan Siklus I. Namun ada beberapa perbaikan yang harus dilakukan oleh peneliti setelah mencermati data-data hasil observasi dan nilai hasil belajar siswa dari Siklus I. Diharapkan perbaikan pada Siklus II dapat mengeliminir kekurangan yang terjadi pada Siklus I. Nilai hasil belajar siswa juga diharapkan lebih meningkat lagi pada Siklus II.

b). Hasil Tindakan Siklus II

Pada Siklus II pelaksanaan tindakan dilakukan sama dengan yang dilakukan pada Siklus I. Yakni terdiri dari 4 tahapan : Planning, Acting, Observing, dan Reflecting. Instrumen yang dipergunakan dalam tindakan Siklus II hampir sama 
dengan Siklus I, hanya saja pembedanya adalah topik gambar berserinya. Media ajar yang dipakai adalah gambar-gambar berseri dengan cerita Cinderella lengkap dengan pewarnaannya. Dari pelaksanaan tindakan yang dilakukan pada Siklus II, diperoleh nilai hasil belajar siswa yaitu nilai terendah 70 , nilai tertinggi 95, nilai rerata 85, dan rentang nilai. Dalam komparasinya dengan hasil Siklus I, tampak bahwa nilai terendah meningkat dari 45 menjadi 70, nilai tertinggi meningkat dari 90 menjadi 95, dan nilai rerata meningkat dari 80 menjadi 85

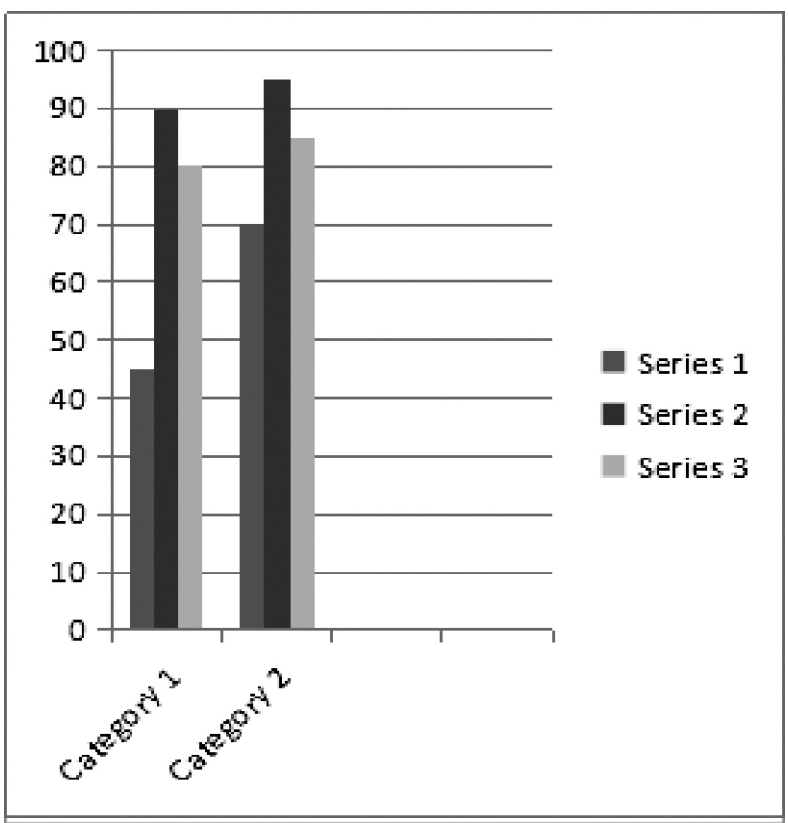

Diagram 2

Perbandingan Siklus I dan Siklus II

Dengan peningkatan nilai rata-rata siswa menjadi 85 dan nilai terendahnya 70 , menjadikan pembelajaran Siklus II tidak ada siswa yang harus diremidi karena nilai KKM 70 sudah tercapai oleh semua siswa. Capaian tersebut menunjukkan bahwa proses pembelajaran dengan menggunakan media gambar berseri sudah berhasil.
E. Hasil Tindakan

Keseluruhan Dari pelaksanaan tindakan Siklus I dan Siklus II yang telah dilakukan pada siswa, ternyata menghasilkan peningkatan nilai hasil belajar. Hal ini terbukti setelah nilai hasil belajar siswa diperbandingkan antara kondisi awal sebelum guru memanfaatkan media gambar berseri yang nilai rata-rata siswa dalam menulis adalah 65, akhirnya meningkat di Siklus II (kondisi akhir) nilai rata-rata siswa menjadi 85, setelah guru memanfaatkan media gambar berseri.

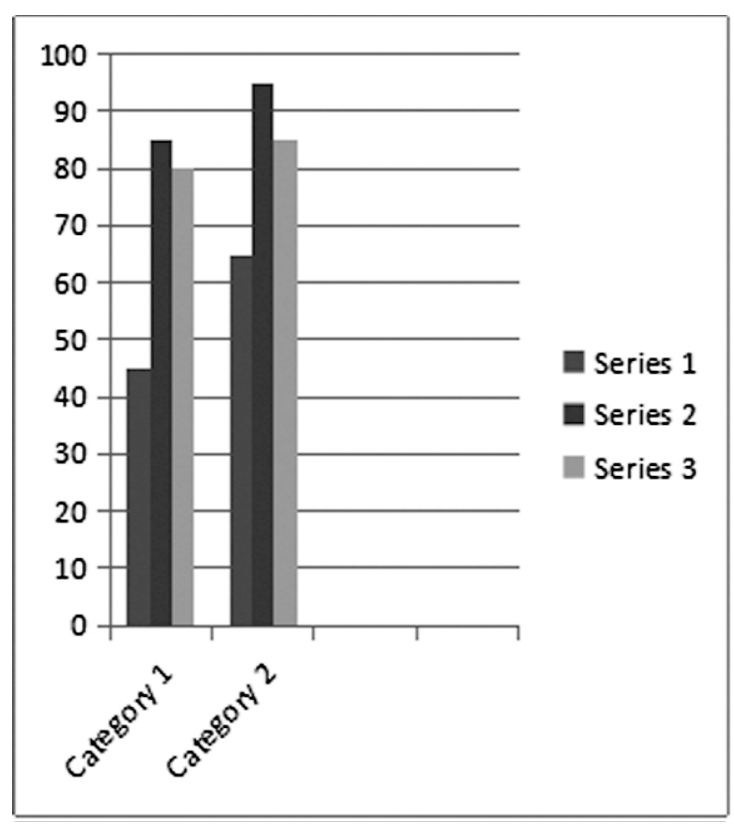

Diagram 3

Perbandingan kondisi awal dan kondisi akhir Pada diagram di atas, nampak bahwa terjadi peningkatan tidak hanya pada nilai rata-rata, namun juga pada perolehan nilai tertinggi siswa. Yang saat kondisi awal nilai tertinggi adalah 80, meningkat pada kondisi akhir (Siklus II) nilai tertingginya menjadi 95. Begitu pula pada saat kondisi awal banyak siswa yang harus diremidi karena perolehan nilai masih di bawah KKM, pada saat kondisi akhir (Siklus II) 
tidak ada lagi siswa yang diremidi karena KKM mampu dicapai atau terlampaui oleh semua siswa kelas VIII .

Demikian pula pada proses kegiatan pembelajaran siswa di kelas VIII-, yang saat kondisi awal siswa cenderung pasif (teacher center), akhirnya menjadi lebih kondusif pada kondisi akhir (Siklus II) dimana siswa menjadi lebih aktif dalam kegiatan pembelajaran di kelas. Bahkan sudah tidak ada lagi siswa yang takut menulis, justru semua siswa tampak senang dan bersemangat melakukan kegiatan menulis.

\section{SIMPULAN}

Dari seluruh rangkaian tindakan yang dilakukan pada Siklus I dan Siklus II, ternyata memberikan hasil yang sangat baik terhadap siswa kelas VIII dalam tujuan pembelajaran Bahasa Inggris untuk meningkatkan ke-mampuan menulis teks narrative dengan me-manfaatkan media gambar berseri. Ternyata dari hasil penelitian yang diperoleh dari kelas VIII menunjukkan bahwa penggunaan media gambar berseri sangat berpengaruh positif bagi siswa.

Saat pelaksanaan tindakan (Siklus I dan Siklus II) berlangsung tidak ada siswa yang mengeluh ketika diberi tugas menulis, hal itu menunjukkan bahwa pemanfaatan media gambar berseri mampu menambah rasa percaya diri siswa bahwa mereka mampu untuk menguasai keterampilan menulis (writing) dengan baik. Walaupun siswa belajar dalam kelompok, ternyata hasil tulisan masingmasing berbeda struktur dan pola kalimatnya. Siswa mampu menulis teks naratif secara mandiri. Pemanfaatan media gambar berseri dalam kelompok ternyata dapat 15 mendidik siswa untuk dapat dipercaya (Trustworthines) untuk menyusun kalimat dan narasi, juga rasa hormat dan perhatian (Respect) kepada guru dan temannya, serta tekun (Diligence) dalam mengerjakan tugas. Maka selain tujuan pembelajarannya tercapai, semua karakter baik tersebut (Trustworthines, Respect, Diligence ) dapat pula ditanamkan pada peserta didik.

Berdasarkan kajian teori dan kerangka berfikir lalu diikuti hipotesa yang diajukan oleh peneliti, serta hasil penelitian yang dilakukan pada siswa kelas VIII, dapat disimpulkan bahwa dengan memanfaatkan media gambar berseri dapat meningkatkan kemampuan menulis berbahasa Inggris narrative text siswa. Penulis merekomendasikan kepada perpustakaan sekolah perlu menyediakan buku gambar berseri agar dapat dijadikan sumber belajar sehingga mendukung pengajaran bahasa Inggris.

\section{SARAN}

Sebaiknya guru bahasa inggris yang membaca penelitian saya ini menggunakan Media gambar berseri yang menarik akan membuat siswa tertarik untuk melihat serta memperhatikan jalan ceritanya mulai awal hingga akhir. Begitu siswa tertarik dan merasa senang untuk menulis, maka mereka lupa bahwa sebelumnya (pada kondisi awal sebelum penggunaan media) mereka merasa terbebani bahkan merasa takut karena tidak tahu apa yang harus ditulis. Pemanfaatan media gambar berseri pada siswa terbukti dapat membangkitkan keaktifan dan motivasi mereka untuk mampu menulis teks narrative berbahasa Inggris. Karena media gambar berseri yang menarik bisa memberikan siswa inspirasi ide-ide cerita 
serta penggunaan kosakatanya terkait dengan cerita yang mereka tulis.

\section{DAFTAR PUSTAKA}

Artono Wardiman, Masduki B. Jahur, M.

Sukirman Djusma. English in

Focus for Junior High

School, Grade VIII. Buku BSE,

Penerbit PT. Bengawan Ilmu.

Filia Dina Anggaraeni. Pembelajaran Melek

Media Pada Siswa Sekolah Dasar

(Pendekatan Teori Belajar

Humanistik). Fakultas Kedokteran

Universitas Sumatera Utara.

http://library.usu.ac.id/download /fk/psiko-filia.pdf.

Hasan Jismulatif, Marzuki. (2017). An Analysis of Student's Ability in Writing at Riau University Pekanbaru Indonesia. Theory and Practice in Language Studies, Vol. 7, No. 5, DOI:

http://dx.doi.org/10.17507/tpls.070 $\underline{5.08}$

Harryanto. 2008. Upaya Peningkatan Keefektifan dan Efisiensi Pembelajaran Bahasa

Inggris pada Siswa. http://one.indoskripsi.com/node/1973.

Intan Karolina. 2006. Teaching Narrative Text in Improving Writing to the Tenth Grade Students of SMA Negeri 1 Petarukan, Pemalang. Skripsi tidak diterbitkan. Universitas Negeri Semarang.

Joko Priyono, Arnys R. Irjayanti, dan Virga Renitasari. 2008. Scaffolding English for Junior High School Students Grade VIII. Jakarta: Pusat
Perbukuan De-partemen
Pendidikan Nasio-nal.

Jismulatif, (2018). Language Attitudes and

Motivation in Learning English of

Students of Physical Education of

FKIP of Universitas Riau. Proceeding

of the 2nd URICES, Pekanbaru,

Indonesia

Mohammad Fadil. Pemanfaatan Media untuk Proses Pembelajaran yang Efektif dan Menyenangkan. http://mfadil.blog.unej.ac.id/pe manfaatan-media-pembelajaran

Meyers, Allan. 2005. Gateways to Academic Writing: Effective Sentences Paragraph and Essay. New York:Longman.

Pangesti. Using Film in the Classroom, Motivational and Inspirational Films.

http://groups.yahoo.com/gro up/cfbe/message/23360

Permendiknas Nomor 41 Tahun 2007 tentang Standar Proses untuk Satuan Pendidikan Dasar dan Menengah.

Permendiknas Nomor 22 Tahun 2006 tentang Standar Isi untuk Satuan Pendidikan Dasar dan Menengah. 